\title{
The Economic Decolonisation of Indonesia: a Bird's-eye View
}

\author{
J Thomas Lindblad \\ Leiden University
}

\section{Introduction}

An oft-quoted statement by the Indonesian nationalist leader Haji Agus Salim runs as follows: 'The economic side of the Indonesian Revolution has yet to begin.' (Higgins, 1957: 102, cited in Lindblad, 2008: 2). The statement was made shortly before or shortly after the transition of sovereignty from Dutch colonial rule on 27 December 1949. At long last, the Netherlands had acknowledged that Indonesia was independent, which brought the Indonesian Revolution to its logical conclusion. But, by the conditions laid down at the Round Table Conference in The Hague in late 1949, the interests of Dutch private capital were still omnipresent in the Indonesian economy. In addition, the Indonesian government was obliged to consult the Netherlands government in matters affecting the economy until the debt of the former colony to the metropolitan mother country had been repaid in full. As Haji Agus Salim rightly stressed, economic and political decolonisation did not coincide but followed different historical trajectories.

This contribution offers an abridged account of the process of economic decolonisation as it unfolded between 1945 and 1959, from the proclamation of independence until the nationalisation of the vast majority of Dutch-owned companies that had retained operations in Indonesia after independence. ${ }^{1}$ Four themes serve as devices to

1 The main reference is my own monograph (Lindblad, 2008). Page references are only given when a specific location is needed. This recapitulation of the main argument has benefited from several 
further our understanding of the process of economic decolonisation. These four themes, in order of appearance, are below: the new spirit in Indonesian economic life following the transfer of sovereignty; the changing climate of economic policy-making during the 1950s; the response and accommodation by remaining Dutch companies; and, finally, the concluding phase of expropriation and nationalisation.

A couple of points of departure need to be spelled out. The ideological basis of the thrust towards economic decolonisation in Indonesia was provided by a small booklet, Ekonomi Indonesia, which made a very timely appearance in 1949. Its subtitle, Dari ekonomi kolonial ke ekonomi nasional, carried an immediate appeal to contemporary public discourse, offering the briefest possible summary of what economic decolonisation in Indonesia was all about. For the remainder, the book offered very little concrete guidance (Hadinoto, 1949). A second point of departure may be traced in the international historiography on Indonesian decolonisation, notably John Sutter's voluminous $\mathrm{PhD}$ dissertation on domestic developments up to the general election in 1955 (Sutter, 1959). Although providing a wealth of information from government sources and press material, Sutter's survey offers little on the fate of private business enterprises; in addition, he did not consult Dutch-language sources. Yet another point of departure in our quest to better understand economic decolonisation in Indonesia is, of course, the wider international context of the Cold War. Decolonisation in Indonesia, whether political or economic, did not take place in a vacuum but was intrinsically linked to Indonesia's efforts to position itself in the tension between the Western powers and the Soviet bloc. Just as Sukarno's young republic secured American support against the returning Dutch by heavy-handedly crushing the Communist uprising in Madiun in 1948; did increasing flirtation with the Soviet bloc during the Guided Democracy period alienate Indonesia from the international

presentations in Indonesia and discussions with Indonesian scholars, including a seminar held at LIPI in Jakarta in January 2012. 
community and bring flows of incoming foreign investment to a virtual standstill?

\section{Novelties of the 1950s}

The very term 'decolonisation' stresses the movement away from a society and economy no longer desired by Indonesians. Yet, economic decolonisation entailed far more than just getting rid of the Dutch. New economic initiatives were taken in the early and mid-1950s that were not necessarily connected with the reduction of retained Dutch economic influence. Such initiatives and the promises they held for future economic development have been overshadowed in the historiography by the more dramatic events in the late 1950s as well as the deterioration into a severe economic crisis in the early and mid-1960s. The overall harsh verdict of macro-economic performance during the Sukarno era easily overlooks the fact that the record of economic growth was reasonably good up to about 1957 (Booth, 1998: 55; Lindblad, 2010: 99).

As a young Minister of Trade and Industry in the Natsir cabinet, Sumitro Djojohadikusumo (1917-2011) took the important step of introducing economic planning in Indonesia. The subsequent Economic Urgency Plan, often labelled the Sumitro Plan, was presented by his department in April 1951, only weeks after the Natsir coalition had been replaced by the Sukiman cabinet. The Sumitro Plan stressed industrialisation to reduce Indonesia's extreme dependence on exports of primary products to the world market, a vulnerability that had become particularly obvious during the worldwide depression of the 1930s. The plan was highly ambitious, in details drawing on ideas circulating in the Dutch colonial administration only in 1941, just months prior to the Japanese invasion. Total outlays during the first two years of implementation amounted to a staggering Rp920 million (Lindblad, 2008: 80-1). Keeping in mind the depreciation of the Indonesian rupiah in 1951, this amount corresponded to Rp2.7 billion or 28 per cent of total government revenue in 1952 (Bank Indonesia, 1955: 64). The main bottleneck was of course 
money. Very little of the Sumitro plan was realised, at any rate, during the Sukarno period. Subsequent efforts at economic planning during the Old Order regime, in particular the Five-year Development Plan for the period 1956-1960 and the Eight-Year Overall Development Plan launched in 1959, bore even less resemblance to actual economic needs in Indonesia. Again, implementation stayed far short of ambition (Thee, 2003: 16-17).

The Hatta cabinet around the time of the transfer of sovereignty had taken the first step in the direction of strengthening Indonesian entrepreneurship. Initiatives were initially confined to designating particular types of import goods for trading by Indonesian nationals, but they fostered the ill-fated Benteng policy of positive discrimination, benefiting indigenous businessmen in particular, which will be discussed in due course in relation to rising economic nationalism. The combined record on three counts-sustained economic growth, economic restructuring and creation of a class of indigenous businessmenwas undeniably bleak and easily makes us overlook what was indeed accomplished.

The early and mid-1950s witnessed a proliferation of newly founded business enterprises in Indonesia. In a rare reference to developments in private business, Sutter estimates that some 500 new firms were set up each year in the early 1950s; indigenous businessmen accounted for 40 per cent of these ventures (Sutter, 1959: 1307). My own analysis of a comprehensive business directory in 1953 reveals that the Indonesian economy at the time counted about 4200 registered business enterprises. Significantly, the share of indigenous businessmen in corporate ownership, judging from owners' names, was scarcely different in trading as opposed to manufacturing, 40 per cent against 33 per cent (Lindblad, 2002: 62-5). More than 1500 new firms were established in Central Java (excluding the city of Yogyakarta) during the 1950s. More than half (52 per cent) had Javanese owners or managers whereas Chinese entrepreneurs accounted for almost one-third (32 per cent). Interestingly, no less than one firm in ten (10 per cent) was set up as a 
joint venture between Javanese and Chinese businessmen (Lindblad, 2008: 89-90). Such statistics convey an impression of a new dynamism in Indonesian economic life during the 1950s that have been connected only loosely or not at all with official policy.

A new elite of indigenous businessmen emerged in the 1950s. The individuals in question, all men, had more often than not benefited from new opportunities for trading that had opened up during the Japanese occupation or during the Indonesian Revolution, although good political connections frequently proved useful in expanding private business undertakings. Statistics are regrettably missing altogether so that we have little choice but to rely on reconstructions done retrospectively at a far later stage. A list compiled in the $1980 \mathrm{~s}$ by political scientist Richard Robison contains names of 21 prominent indigenous Indonesian businessmen in the 1950s. The list includes well-known figures such as Agoes Dasaad, Soedarpo Sastrosatomo, Hasjim Ning, TD Pardede, Djohan and Djohor, Eddy Kowara, and Fritz Eman (Robison, 1986: 51). The Sumatran, Hasjim Ning (1916-1995), nephew of Vice-President Mohammad Hatta, held the exclusive import agency for General Motors and was widely known as the 'Henry Ford of Indonesia'. Soedarpo (1920-2007), of Javanese descent but raised in Sumatra, collected import licences and made a fortune in shipping. TD Pardede (1916-1991), a Batak Protestant, founded a business empire in Medan and was allegedly the first one to apply the label 'Made in Indonesia' to his textile exports.

A somewhat unconventional approach to find out more about the business elite of the 1950s is to consult details on company history for the country's 200 leading conglomerates as documented around 1990. This retrospective analysis demonstrates that 40 of the 200 largest business enterprises in 1990 had operations dating from the 1950s or before. This 'old elite' was equally populated by indigenous and Chinese businessmen, about 20 conglomerates for each category. However, only five members of the indigenous business elite as constructed by Robison showed up among the 200 top conglomerates around 1990. 
These five were Hasjim Ning, Soedarpo, Pardede, Eddy Kowara and Fritz Eman (Udatin). Other leading indigenous conglomerates around 1990-Bakrie, Haji Kalla, TM Gobel, Julius Tahija (Indrapura) and Arnold Baramuli (Poleko ) - had, in the 1950s, apparently been in an infant or formative stage of building up their business enterprises. The adjoining list of Chinese-owned conglomerates that had started out no later than in the 1950s includes names such as Djarum, Bentoel, Lautan Luas, Gayah Tunggal, Mantrust, and, of course, the two at the very top: the Salim concern and Astra International (Lindblad, 2008: 96-101). The comparison by way of looking backward from 1990 teaches us that the new dynamism in Indonesian business during the 1950s was sometimes, yet far from always, sustained in the long run, and also that ventures by Indonesians of Chinese descent were not seriously hindered by discriminatory policies in the Sukarno era.

\section{A change of climate}

There is a tradition in the international historiography to distinguish between two opposite camps in the economic leadership in Indonesia during the 1950s (Higgins, 1957: 103; Feith, 1962: 113). The so-called 'economics-minded' pragmatic administrators held the stage throughout the early 1950s whereas the 'history-minded' nationalists predominated in the mid and late 1950s. Vice-President Hatta and Sumitro Djojohadikusumo, both trained as economists in the Netherlands, belonged to the former camp and so did Sjafruddin Prawiranegara (1911-1989), who had studied law at Leiden University and who, in 1951, served as the first Indonesian president of the nation's central bank. In the opposite camp we come across Iskaq Tjokrohadisurjo, Minister of Economic Affairs in the first Ali Sastroamidjojo cabinet, known as a vigorous advocate of discrimination in favour of indigenous Indonesian entrepreneurs as institutionalised in the Benteng program; in the event, he had to resign his post because of corruption charges before the Ali cabinet had completed its term in office. Foremost among the 'history-minded' politicians was of course President Sukarno 
himself, prime 'solidarity-maker' of Indonesia of his generation. A more difficult person to fit into this dichotomy is Djuanda Kartawidjaja (1911-1963), an engineer by training and ostensibly known for his lack of party affiliation while Prime Minister and head of the 'working cabinet' (kabinet kerja) that bridged the transition from constitutional democracy to the Guided Democracy period in the years 1957 to 1959.

The pragmatic economic policy-makers derived their inspiration from a mixture of classical capitalist economic theory and idealism with roots in European social democracy. Sumitro was a member of the minuscule socialist party, PSI (Partai Sosialis Indonesia), whereas Hatta saw the cooperative as the ideal compromise to face the huge economic challenges of the nation. A lively exchange of ideas took place, partly in Dutchlanguage journals. A comparison of the viewpoints of Sumitro and Sjafruddin reveals that the former, as a professional economist, probably had a more realistic grasp of the economic situation in Indonesia (Thee, 2010). The pragmatic policy-makers agreed between them that foreign capital and know-how was indispensable for economic development in Indonesia during the early post-independence period. This viewpoint was obviously not shared by the economic nationalists.

Economic decolonisation under the banner of pragmatism assumed the form of co-operation and voluntary nationalisation in a highly selective manner. Interventions only affected economic activities deemed to be of direct public or national interest such as the central bank, the national carrier, public utilities and public transport. A model of cooperation with the former colonial power evolved with the foundation of Garuda Indonesian Airways in March 1950. The airline was set up as a joint venture with the Indonesian state holding 49 per cent of the share capital and the KLM (Royal Dutch Airlines) keeping a 51 per cent majority share for the time being. A contract for management and training was concluded with KLM. After considerable parliamentary pressure, the Indonesian state in 1954 purchased all remaining shares in Garuda and expiration of the management contract was envisaged within six years. In the event, co-operation with the KLM ceased in 
December 1957 when Dutch firms at large were taken over (Lindblad, 2008: 113-15).

A similar type of co-operation would have been logical in the crucial sphere of inter-island shipping, which was traditionally controlled by the Dutch-owned KPM (Koninklijke Paketvaart Maatschappij, Royal Packet Company). Because of KPM opposition, the Garuda model could not be replicated, forcing the Indonesian government to opt for competition rather than co-operation. The subsequent state-owned shipping concern, PELNI (Pelayaran Nasional Indonesia, National Indonesian Shipping), was founded in 1952, operating a fleet of ships taken over from a national foundation to further indigenous Indonesian shipping. Competition between KPM and PELNI took place on unequal terms, the former drawing on a large fleet and much accumulated knowhow and the latter only supported by government protection. Statistics on productivity during the years before and after the expulsion of KPM from Indonesian waters show that PELNI was operating far less efficiently than KPM (Marks, 2009: 170).

In 1949, it had been a rather controversial decision to choose the Dutchmanaged Java Bank as the nation's central bank rather than the BNI (Bank Negara Indonesia, Indonesian National Bank), which had fulfilled this function for the Republic during the Indonesian Revolution. The purchase by the Indonesian government in 1951 of all privately held Java Bank shares in the Amsterdam Stock Exchange inaugurated a model for voluntary nationalisation in which compensation was paid at market prices. An immediate effect of the change in ownership was the appointment of Sjafruddin Prawiranegara as the bank's first Indonesian president, chairing a board of directors with the smallest possible Indonesian majority and a layer of Dutch high-level bank managers. In 1953, the bank's name was altered to Bank Indonesia and less restrictive credit policies were announced, notably to aid indigenous Indonesian entrepreneurship (Lindblad, 2008: 104-12). For international transactions, the Indonesian economy remained highly 
dependent on a number of foreign-owned commercial banks, including three with Dutch owners (NHM, Escompto Bank, and Handelsbank).

Other examples of voluntary nationalisation occurred in 1954 and included public utilities such as gas and electricity companies in Jakarta and selected other regions (Cirebon, Central and East Java, Balikpapan and Ambon) as well as public transport in metropolitan Jakarta. Port facilities in Surabaya followed suit in 1956 and in 1957 there was mounting pressure to nationalise also Dutch-owned railway companies in Java and Sumatra. However, it was becoming increasingly difficult to negotiate the right price for takeover and the Indonesian state was obviously not in a position to finance a nationalisation of the numerous Dutch-owned firms in estate agriculture, mining, manufacturing and trading that were still in operation by 1957.

The shift to economic nationalism occurred gradually, from July 1953 onwards, during the first cabinet headed by Ali Sastroamidjojo. The PNI (Partai Nasional Indonesia) supplied the most vocal advocates of a renewed nationalism, in particular, Minister of Economic Affairs Iskaq Tjokrohadisurjo, whereas the coalition partner, the Muslim party NU (Nahdlatul Ulama), exerted less of a countervailing influence than Masjumi, the other main Islamic party, had shown in earlier coalitions. One of Masjumi's leading personalities was, not coincidentally, Sjafruddin Prawiranegara. Demands to speed up economic nationalisation became more outspoken, in parliament and from leftist trade unions. Meanwhile, no agreement could be reached with the Netherlands on the future status of western New Guinea (Irian Barat, now Papua) and the Indonesian government began putting the matter before an international audience, notably the United Nations.

The Benteng policy was escalated under Iskaq Tjokrohadisurjo, numbers of designated national importers rose to 4000 but it was widely known that a vast majority of the indigenous traders sold their licences for use by Chinese and European firms. Corruption in offices entrusted with executing the policy was rampant and the whole Benteng concept rapidly degenerated into a public scandal. Objectives, in the sense of 
meeting stated targets, were not met and the policy's failure was likely to have eroded Indonesian confidence in the workings of a capitalist economy. In addition, Benteng provided a comfortable platform for overt anti-Chinese action. In 1956, the Assaat movement rallied indigenous businessmen against Chinese rivals but the commotion soon subsided. Three years later, in 1959, such actions resurfaced with the government's infamous expulsion of traders of Chinese descent from towns and villages (Thee, 2003: 12-13, 2009: 316; Lindblad, 2008: 129-36, 139-47). The Benteng policy contributed little to actual economic decolonisation, let alone the creation of a class of indigenous businessmen. Its main effect was to pave the way for more drastic measures, against the Dutch and the Chinese, whilst unintentionally widening the scope for direct state intervention in the economy.

\section{The Dutch response}

According to an oft-cited statistic, by the early 1950 s, the eight leading Dutch trading corporations were still handling 60 per cent of all imports of consumer goods, which in turn corresponded to half of all goods imported to Indonesia. The group of eight included the famous 'Big Five': Borsumij, Internatio, Jacobson van den Berg, Lindeteves and Geo. Wehry (Glassburner, 1971: 78-9). It is hazardous to conjecture how much of the immediate post-independence economy of Indonesia was in fact controlled by private Dutch capital interests. Foreign, in particular, Dutch, domination was particularly strong in large parts of what one may call the 'modern' sector of the economy. It is likely that more than half of all export earnings accrued to foreign-owned production lines among which Dutch investment was still paramount (Lindblad, 2008: 38). Corporate assets had by and large been returned to Dutch owners after the Indonesian Revolution and Dutch business firms were guaranteed unhindered continued operations in Indonesia under the financial and economic agreement, Finec, preceding the transfer of sovereignty. This was a major concession on the part of the Republic and it was only matched by a vaguely worded commitment 
by Dutch firms to further indonesianisasi of management by promoting Indonesian nationals to supervisory positions (Round Table Conference, 1950). Except for a limited number of firms affected by voluntary nationalisation in the early 1950 s, virtually all Dutch-owned companies were in business by 1957 .

Conditions of operating a private firm were dramatically different compared to the colonial period before the Pacific War. Records of Dutch business firms abound with complaints of militant trade unions, exorbitant wage demands, land occupations at estates, thefts and sabotage, strikes, and bureaucratic regulations, in particular, with respect to transmitting profits to owners in the Netherlands. There was clearly an urgent need to redefine business strategies. The chief choice was between the options of leaving Indonesia, possibly with the intention of continuing elsewhere, and accommodation through adjustment to the changing circumstances. Some firms did try to emulate their success on Indonesian soil at other locations, for instance, by trying to cultivate sugar in Ethiopia or setting up trading agencies in Africa or Latin America. Most of these ventures met with failure and only resulted in losses (Sluyterman, 2003: 220-1).

A key reason to stay on and make the best of the situation was of course the high profitability of doing business in Sukarno's Indonesia during the 1950s, a time when world market prospects were favourable for Indonesian export commodities. Profit remittances to Dutch owners are estimated at Rp1.1 billion in 1953, Rp840 million in 1954 and somewhere in the range Rp810-970 million for 1955-figures that may be offset against the total debt of the Indonesian government with Bank Indonesia in 1955, Rp6 billion (Lindblad, 2008: 159; Bank Indonesia, 1956: 68). There was increasing uneasiness among leading Dutch businessmen about the stubborn resistance by the Netherlands government to giving up western New Guinea. One group, led by Unilever executive Paul Rijkens, even approached President Sukarno in an attempt to reach a secret understanding outside the Dutch-Indonesian negotiations in Geneva in 1955 and 1956 (Meijer, 1994: 553-4). 
Apart from the dismal record of ventures elsewhere and the continued high profitability, there was a third reason for Dutch business firms to choose the strategy of accommodation: the unshakable conviction that Dutch know-how was absolutely essential to economic development in Indonesia. Independent Indonesia simply could not do without Dutchmen - that was the firm belief often expressed in private (Sluyterman, 2003: 218-9; Kerkhof, 2005: 199). Such an attitude testified to a loss of touch with reality.

The commitment on the part of Dutch enterprises to improve the position of Indonesians in management, so that eventually 'the majority of the supervisory would consist of Indonesian citizens' (Round Table Conference, 1950), increasingly became a hotly debated issue in contacts between the government and Dutch firms. The record was a mixed one. Some large companies, notably Royal Dutch Shell through its subsidiary BPM (Bataafsche Petroleum Maatschappij, Batavian Petroleum Company), became known for a speedy implementation of policies of indonesianisasi, including training and replacement of Europeans by Indonesians in numerous higher functions. Other leading Dutch firms such as the tin-mining company Billiton only made efforts after intervention from the highest circles of government. Progress was also slow in banking, allegedly because of the acute shortage of banking skills among Indonesian employees (Lindblad, 2008: 161-6).

Monitoring the process of indonesianisasi was difficult because no targets or deadlines had been specified. In addition, there was the continuous confusion whether indonesianisasi should benefit persons with the Indonesian nationality or those of indigenous descent, a similar ambiguity as in the implementation of positive discrimination under the Benteng program. The trading firm Internatio, one of the 'Big Five', did create a new category of high-level staff but in 1957 it transpired that more than half of its members were of Chinese descent, which was not at all what the authorities had urged (Kerkhof, 2005: 194-7). A rather typical example of the slow progress is found in the agricultural estate company, LMOD (Landbouw-Maatschappij Oud-Djember, Old 
Jember Agricultural Company), where Dutchmen still held 26 of 35 management positions by 1957 (Lindblad, 2008: 170). Some of the indonesianisasi that did take place after all, was in fact brought about by increasing practical problems in obtaining entry permits for expatriates and recruiting suitable Dutchmen for work in Indonesia.

It is instructive also to review the generally unimpressive record of Dutch firms with respect to indonesianisasi in a comparative perspective, in particular, by considering developments in non-Dutch foreign firms operating in Indonesia at the time. Scarce evidence, virtually only pertaining to American oil companies (Caltex and Stanvac) and to the Anglo-Dutch manufacturing firm Unilever, does suggest a greater willingness to train Indonesians and promote them to higher positions than in most Dutch-owned firms (Lindblad, 2008: 171-5). It is probable that more could have been realised in terms of indonesianisasi in Dutchowned companies up to 1957 than actually happened. From a slightly different comparative perspective, that of British firms in Malaya/ Malaysia, it can be inferred that indigenisation of higher staff rarely, if ever, took place voluntarily (Kerkhof, 2009: 191-3).

The Dutch corporate response to the changing conditions of operations in Indonesia following the transfer of sovereignty was characterised by a number of ambiguities. A stubborn belief in a long-term continuity of the task to be undertaken in Indonesia was accompanied by short-run strategies of maximising profit remittances at the expense of reinvesting gains. Accommodation and adjustment to changing circumstances took precedence over exit strategies but failed to embrace the alteration of management hierarchies to which the Dutch corporate world in Indonesia had committed itself. A crucial question is whether the limited progress in terms of indonesianisasi can be linked to the takeover and subsequent nationalisation. Whether the takeovers could have been averted altogether, more progress with indonesianisasi would surely have made it more difficult for economic nationalists in Indonesia to call for outright expropriation of Dutch companies. 


\section{The final phase}

The expression 'Black Santa Claus' (Zwarte Sinterklaas) is eternally engraved in the memories of Dutchmen whose corporate premises were taken over by local trade unions all over Indonesia on 3 December 1957 and during subsequent weeks. The immediate cause was Indonesia's failure to get the conflict with the Netherlands about the status of western New Guinea on the agenda of the United Nations. Massive propaganda during preceding months had anticipated direct action against the interests of Dutch capital in the highly probable case that Indonesia would not succeed in gathering sufficient votes in the General Assembly. Therefore, it is all the more remarkable that the Dutch staff in the seized companies was apparently taken by complete surprise. Significantly, the takeovers began at the Jakarta office of the KPM, the very embodiment of retained predominance of the former colonial power in the economy of independent Indonesia. Djuanda's 'working cabinet' acted with great speed placing all expropriated Dutch-owned companies - more than 700 firms - under military command, ostensibly to prevent leftist trade unions and the Communist Party from gaining control of the nation's major productive assets (Lindblad, 2008: 181-6; Feith, 1962: 584).

There has been some discussion in the international historiography about whether the takeovers were premeditated by the government (Gardner, 1997: 142). Some stress the apparent lack of planning and coordination necessitating continuous improvisation by the authorities, a point also made by Sjafruddin Prawiranegara, who criticised the actions and in fact stepped down as central bank president shortly afterwards (Kahin and Kahin, 1995: 11). Others discern orchestration by the government behind the systematic propaganda campaign preceding the actions and note that Sukarno himself at a later stage boasted about the takeovers as a personal achievement (Gardner, 1997: 142). A more probable theory is that the takeovers sprouted forth from the logic of a dramatic and highly volatile situation in which Dutch firms became a handy scapegoat for everything that was going wrong and the President 
himself had barely survived an attempt at assassination (Kanumoyoso, 2001: 106-7). Sukarno might have sensed something was going to happen without knowing the details, and when it did happen, there was no way back (Glassburner, 1971: 92).

Throughout the year 1958 and far into 1959, most of the seized companies remained legally Dutch property, although being managed by Indonesians after the Dutch supervisory staff had been forced to leave the country. Only in December 1958 was legislation on the nationalisation of Dutch firms approved by parliament. The law was implemented in waves of nationalisation during the better part of 1959. All agricultural estates were rearranged under the umbrella of a new national organisation, PPN-Baru (Pusat Perkebunan NegaraBaru, Central [Organization of] State-owned Estates, New-styled). Some trading companies were privatised and acquired by Chinese conglomerates (Lindblad, 2008: 188-94). As a direct consequence of the change of ownership, participation by the Indonesian state in the economy was significantly increased and has remained so ever since.

The transition from takeover to formal nationalisation was a rather drawn-out one that involved a great deal of adjustment and improvisation in management and supervision. For the hastily promoted Indonesian managers, it was literally a matter of running somebody else's business. The interval between takeover and legal change of ownership hints at the possibility that the actions in December 1957 did not primarily aim at nationalisation as such but were deployed as weapons in the escalating conflict with the Netherlands. However, the necessity of accomplishing economic decolonisation ruled out a return of the seized property to the rightful owners. Here it is instructive to make a comparison with the seizure of British and American firms some years later during the so-called Konfrontasi against Malaysia (1963-1966). Firms were taken over in the context of conflict and indeed returned to owners when the Suharto government had assumed the reins of power and the conflict with Malaysia was brought to a conclusion. The actions against Dutch firms may very well have started in 1957 in much the same way as 
subsequent actions during the Konfrontasi. The outcome turned out very differently because of the link with decolonisation.

Nationalisation may be conceived as the ultimate form of indonesianisasi, the final phase of economic decolonisation. Indonesian nationalisation of corporate Dutch property was recognised under international law because of the commitment to pay compensation laid down in the legislation approved by the Indonesian parliament. Actual recognition was achieved at a court case in Bremen in Germany in 1959 where one of the Dutch-owned tobacco companies in North Sumatra had formally protested against auctions of tobacco from its estate. This was without doubt an important victory for the Indonesian government, which had even mobilised former Nazi Reichsbank president, Hjalmar Schacht, to testify in its favour (Lindblad, 2008: 196-7).

Negotiations with the Netherlands about compensatory payment were slowed down by the growing tensions in Indonesia during the early 1960s. At long last, in 1966, a settlement was reached by which the Indonesian state promised to pay a total of 689 million guilders to the Dutch, consisting of 600 million guilders indemnification and accumulated interest. Payments commenced in 1973 and were completed by 2003 . The amount paid was a far cry from what the Dutch firms had claimed by way of indemnification. In 1959, some 250 nationalised firms filed a collective claim of 1.5 billion guilders. Aggregate claims for all 700-odd nationalised firms approached 2.7 billion guilders which was still below the stated book value, a staggering 4.5 billion guilders (Jong and Lessing-Sutherland, 2004: 23-4; Lindblad, 2008: 198). The Indonesian side repeatedly asserted that the stated book values were gross exaggerations considering that Dutch firms by and large had undertaken very little new investment during the post-war period.

There is also some discussion in the international historiography on the effect of the takeover and nationalisation of Dutch firms on economic performance in Indonesia. An immediate dip took place in 1958, which at least partly must be attributed to the sudden transfer of management of vital economic assets from Dutch to Indonesian supervisors. Total 
export revenues fell by 22 per cent, from Rp11.1 billion to Rp8.6 billion, but the downward trend was reversed in 1959. The subsequent decline, down to Rp9.6 billion in 1960, reflected falling oil prices in world markets and a drop in rubber output for estates and for smallholders. Scattered evidence also suggests that the global dimensions of estate agriculture in North Sumatra with respect to employment and planted area remained largely unaffected by the tumultuous events in 1958 and 1959 (Bank Indonesia, 1958: 128-9, 1966: 109-11 Lindblad, 2008: 200-1). Trade with the Netherlands obviously came to a complete standstill but export were diverted to other European markets as seen in the case of Sumatra tobacco auctioned in Germany in 1959. The dip in 1958 , and possibly also in 1959 , does not seem to have been sustained into the early 1960s. There was no direct continuity between the takeover of Dutch firms in 1957 and the severe economic crisis in the mid-1960s.

An alternative view emphasises economic and institutional damage inflicted on Indonesia by the very way in which economic decolonisation took place. Lack of managerial and technical know-how after the expulsion of the Dutch caused a long-run deterioration in terms of efficiency and productivity, as may be gathered from a comparison of the performance of PELNI with that of the preceding KPM (Marks, 2009: 171-2). A comparison with economic decolonisation in Malaysia is similarly likely to underscore the importance of how economic decolonisation was achieved. Upon gaining full independence in 1957, Malaysia immediately joined the British Commonwealth and the interests of British investment remained intact for another two decades (Lindblad, 2003: 44-8). Although the process of economic decolonisation in itself without doubt caused more damage in Indonesia than in Malaysia, it appears that the chief responsibility for the vast difference in macro-economic performance during the 1960s lay in the economic policies as pursued by the Sukarno administration during the final years. 


\section{Conclusion}

A bird's-eye view of economic decolonisation in Indonesia needs to zoom in on what made the process differ from that of political decolonisation. The first observation refers to timing. Economic decolonisation was not only completed at a far later point in time than political decolonisation, fourteen years after the proclamation of independence or a full decade after the transfer of sovereignty, the process was also slower in getting started. We may identify a preliminary stage of embryonic economic decolonisation during the Japanese occupation and the Indonesian Revolution (1942-1949), which for reasons of brevity of argument has not been discussed here. Unexpected opportunities availed themselves for ambitious Indonesians to take over management tasks in expectation of the arrival of Japanese administrators or because the rightful Dutch owners had not yet gained access to their property. Yet, the accumulated know-how of such experience appears to have been limited just as was the case also with economic policy-making by the republican government prior to the transfer of sovereignty (Lindblad, 2008: 47-74).

The middle phase of economic decolonisation lasted from 1950 to 1956 and was characterised by three seemingly unrelated developments. The first one was the new dynamism in Indonesian economic life as manifested by the establishment of considerable numbers of new business enterprises, either despite or somehow, however indirectly, furthered by the failed Benteng policy of positive discrimination. The second important shift concerned the successive replacement of pragmatism by nationalism in economic policy-making, which arguably formed a precondition for speeding up the entire process. The third point refers to the response of Dutch firms retaining operations in Indonesia, inclined to remit as much profit as possible but reluctant to let Indonesians take a share in management responsibilities.

The final phase of economic decolonisation, 1956-1959, was shorter and more dramatic than the preceding one, complete with takeovers and formal nationalisation of Dutch-owned companies and a virtual 
collapse of Dutch-Indonesian relations for the time being. It needs to be stressed, however, that this culmination of the process of economic decolonisation went accompanied by no violence and that compensation was eventually paid for the expropriated firms. Whether the compensation was sufficient or not, there can be no doubt that the loss of capital and know-how was very substantial. The price of economic decolonisation was very high for Indonesia and for the Netherlands.

\section{Bibliography}

Bank Indonesia. (1955). Report for the year 1954-1955. Jakarta: Kolff.

Bank Indonesia. (1956). Report for the year 1955-1956. Jakarta: Kolff.

Bank Indonesia. (1960). Report for the year 1959/60. Jakarta: Kolff.

Bank Indonesia. (1966). Report for the years 1960/65. Jakarta: Kolff.

Booth, Anne. (1998). The Indonesian economy in the nineteenth and twentieth centuries: a history of missed opportunities. Basingstoke: Macmillan.

Feith, Herbert. (1962). The decline of constitutional democracy in Indonesia. Ithaca: Cornell University Press.

Gardner, Paul F. (1997). Shared hopes, separate fears: fifty years of U.S.-Indonesian relations. Boulder: Westview.

Glassburner, Bruce. (1971). 'Economic policy-making in Indonesia, 1950-1957'. In Bruce Glassburner (ed.). The economy of Indonesia. Ithaca: Cornell University Press.

Hadinoto, Soejono. (1949). Ekonomi Indonesia: dari ekonomi kolonial ke ekonomi nasional. Jakarta: Yayasan Pembangunan.

Higgins, Benjamin. (1957). Indonesia's economic stabilization and development. New York: Institute of Pacific Relations.

Jong, JJP de and DME Lessing-Sutherland. (2004). To forget the past in favour of a promise for the future: Nederland, Indonesië en de financiële overeenkomst van 1966: onderhandeling, regeling, uitvoering. Den Haag: Ministerie van Buitenlandse Zaken [Ministry of Foreign Affairs].

Kahin, Audrey R and George McT. (1995). Subversion as foreign policy: the secret Eisenhower and Dulles debacle in Indonesia. New York: Norton.

Kanumoyoso, Bondan. (2001). Nasionalisasi perusahaan Belanda di Indonesia. Jakarta: Sinar Harapan.

Kerkhof, Jasper van de. (2005). 'Indonesianisasi of Dutch economic interests, 19301960: the case of Internatio'. Bijdragen tot de Taal-, Land- en Volkenkunde, 161: 181-209.

Kerkhof, Jasper van de. (2009). "Colonial” enterprise and the indigenization of management in independent Indonesia and Malaysia'. In J Thomas Lindblad 
and Peter Post (eds). Indonesian economic decolonization in regional and international perspective. Leiden: KITLV Press.

Lindblad, J Thomas. (2002). 'The importance of indonesianisasi during the transition from the 1930 s to the 1960s', Itinerario. European journal of overseas history, 26(3-4): 51-72.

Lindblad, J Thomas. (2003). 'The economic impact of decolonization in Southeast Asia: economic nationalism and foreign direct investment, 1945-1965'. In Marc Frey, Ronald W Pruessen and Tan Tai Yong (eds). The transformation of Southeast Asia: international perspectives on decolonization. Armond/London: Sharpe.Lindblad, J Thomas. (2008). Bridges to new business: the economic decolonization of Indonesia. Leiden: KITLV Press.

Lindblad, J Thomas. (2010). 'Economic growth and decolonisation in Indonesia'. Itinerario, 34(1): 97-112.

Marks, Daan. (2010). 'The economic consequences of decolonization; the "special" case of Indonesia'. In J Thomas Lindblad and Peter Post (eds). Indonesian economic decolonization in regional and international perspective. Leiden: KITLV Press.

Meijer, Hans. (1994). Den Haag-Jakarta; de Nederlands-Indonesische betrekkingen 1950-1962. Utrecht: Aula.

Robison, Richard. (1986). Indonesia; the rise of capital. North Sydney: Allen \& Unwin.

Round Table Conference. (1950). Results as accepted in the second plenary meeting held on 2 November 1949 in the Ridderzaal at The Hague. Jakarta: Kolff.

Sluyterman, Keetie E. (2003). Kerende kansen; het Nederlandse bedrijfsleven in de twintigste eeuw. Amsterdam: Boom.

Sutter, John O. (1959). Indonesianisasi; a historical survey of the role of politics in the institutions of a changing economy from the Second World War to the eve of the general election, 1940-1955. (PhD thesis, Cornell University, Ithaca).

Thee Kian Wie (ed.). (2003). Recollections: the Indonesian economy, 1950s-1990s. Singapore: Institute of Southeast Asian Studies.

Thee Kian Wie. (2009). 'Indonesianization; economic aspects of decolonization in Indonesia in the 1950s'. In J Thomas Lindblad and Peter Post (eds). Indonesian economic decolonization in regional and international perspective. Leiden: KITLV Press.

Thee Kian Wie. (2010). 'The debate on economic policy in newly independent Indonesia between Sjafruddin Prawiranegara and Sumitro Djojohadikusumo'. Itinerario. European journal of overseas history, 34: 35-56. 